\title{
Bio-prospecting of cuttle fish waste and cow dung for the production of fibrinolytic enzyme from Bacillus cereus IND5 in solid state fermentation
}

\author{
Gurupatham Devadhasan Biji ${ }^{1}$ - Arumugaperumal Arun ${ }^{2}$ • \\ Eswaran Muthulakshmi ${ }^{2}$ Ponnuswamy Vijayaraghavan ${ }^{3}$. \\ Mariadhas Valan Arasu' ${ }^{4}$ Naif Abdullah Al-Dhabi ${ }^{4}$
}

Received: 1 August 2016/Accepted: 19 October 2016/Published online: 28 October 2016

(C) The Author(s) 2016. This article is published with open access at Springerlink.com

\begin{abstract}
The process parameters governing the production of fibrinolytic enzyme in solid state fermentation employing Bacillus cereus IND5 and using cuttle fish waste and cow dung substrate were optimized. The $\mathrm{pH}$ value of the medium, moisture content, sucrose, casein and magnesium sulfate were considered for two-level full factorial design and $\mathrm{pH}$, casein and magnesium sulfate were identified as the important factors for fibrinolytic enzyme production. Central composite design was applied to investigate the interactive effect among variables $(\mathrm{pH}$, casein and magnesium sulfate) and response surface plots were created to find the pinnacle of process response. The optimized levels of factors were $\mathrm{pH} 7.8,1.1 \%$ casein and $0.1 \%$ magnesium sulfate. Enzyme production was increased 2.5-fold after statistical approach. The enzyme was purified up to a specific activity of $364.5 \mathrm{U} / \mathrm{g}$ proteins and its molecular weight was $47 \mathrm{kDa}$. It was stable at $\mathrm{pH}$ 8.0 and was highly active at $50{ }^{\circ} \mathrm{C}$. The mixture of cuttle fish waste and cow dung could find great application as solid substrate for the production of fibrinolytic enzyme.
\end{abstract}

Ponnuswamy Vijayaraghavan

venzymes@gmail.com

1 Department of Zoology, Nesamony Memorial Christian College, Marthandam, Kanyakumari, Tamil Nadu 629 165, India

2 Department of Biotechnology, Kalasalingam University, Virudhunagar, Srivilliputtur, Tamilnadu 626 126, India

3 Centre for Marine Science and Technology, Manonmaniam Sundaranar University, Rajakkamangalam, Kanyakumari, Tamil Nadu 629 502, India

4 Department of Botany and Microbiology, Addiriyah Chair for Environmental Studies, College of Science, King Saud University, P. O. Box 2455, Riyadh 11451, Saudi Arabia
Keywords Cuttle fish waste $\cdot$ Cow dung . Solid state fermentation · Fibrinolytic enzyme - Bacillus cereus IND5 · Thrombolytic therapy

\section{Introduction}

Cardiovascular diseases (CVDs) namely, coronary heart disease, acute myocardial infarction and atherosclerosis are the leading cause of death. Among these CVDs, thrombosis is one of the most important diseases (Wang et al. 2006). CVDs are treated by the extensive use of tissue-type plasminogen activator (t-PA), urokinase and streptokinase among other fibrinolytic agents (Holden 1990). However, these fibrinolytic agents cause allergic reactions, bleeding complications and short half-lives (Blann et al. 2002; Bode et al. 1996; Turpie 2002). Hence, the search is still vibrant for new and safer fibrinolytic enzymes throughout the world. In recent years, microbial fibrinolytic enzymes have been considered cost effective among the other fibrinolytic enzymes. These enzymes have been extensively studied from insects (Ahn et al. 2003), snake venom (He et al. 2007), and marine organisms (Sumi et al. 1992). Fermented foods namely, natto (Sumi et al. 1987, 1990; Fujita et al. 1993, 1995), Chungkook-Jang (Kim et al. 1996) and Tempeh (Sugimoto et al. 2007) have also been the source of fibrinolytic enzyme isolation. Apart from therapeutic applications, fibrinolytic proteases continue to be attractive as their potent activity on blood clot (He et al. 2007), Keratin (Bressollier et al. 1999) and collagen (Itoi et al. 2006) could have important industrial waste management and medical applications.

Solid state fermentation (SSF) is emerging as an efficient technique for production of enzymes and bioconversion of metabolites. Agro-industrial wastes, waste water 
and fishery wastes were utilized as cost-effective substrates in processes of biomolecule production. The agro-wastes namely, green gram husk (Prakasham et al. 2006), cake of Jatropha curcas seed (Mahanta et al. 2008), ground nut husk (Salihu et al. 2014), copra waste (Dilipkumar et al. 2013) and wheat bran and deproteinized acid cheese whey (Raol et al. 2015) were used successfully as the substrate for the enzyme production. The ideal substrate should be cheap so as to reduce the production cost of biomolecules (Pandey et al. 2000). In SSF process, the solid substrate provides required nutrient to the growth of microbes and enzyme production. Hence, the solid substrate employed for any bioprocess should be rich in nutrients for the production of biomolecules. Recently, there is an increase in the exploitation of resources from marine wastes. About 105.6 million tons of fish resources were utilized for human consumption and 34.8 million tons ( $25 \%$ of the fish resource) are treated as waste. The fishery waste includes whole fish waste, viscera, bones, skin, fish head, gonads, frame liver, muscle tissue and other parts (Awarenet 2004). However, these wastes were left unused or buried along sea shore which causes pollution to the environment (Bozzano and Sardà 2002). Several studies were carried out to utilize these wastes as substrate for enzyme production. The fish wastes included fish meat wastes (Vázquez et al. 2006), head and viscera powder (Triki-Ellouz et al. 2003) and waste water (Haddar et al. 2010). These fish wastes were rich of proteins, amino acids and oils (Ghaly et al. 2013). On the other hand, cow dung is one of the cheapest biomass which proved to be a useful substrate in protease (Vijayaraghavan and Vincent 2012), cellulase (Vijayaraghavan et al. 2016a) and fibrinolytic enzyme (Vijayaraghavan et al. 2016b) production in SSF. It contains cellulose, carbon, hemicelluloses, ions and trace elements (Fulhage 2000) and it could be a novel feedstock for better growth of microorganisms (Adegunloye et al. 2007). Considering the nutritive value of fish waste and cow dung, this combination of feedstock was used as the solid substrate for fibrinolytic enzyme production.

Statistical designs of experiments help to find the important variable and concentration of variables for biomolecules production. These were traditionally evaluated by one-factor-at-a-time strategy. However, it fails most often to nail down the correct response in an enzyme bioprocess and this can be overcome by statistical experimental design. The statistical designs such as fractional factorial design (Liu et al. 2005), Plackett-Burman (Dilipkumar et al. 2011) and $\mathrm{L}_{18}$-orthogonal array (Mahajan et al. 2012) were used to screen the significant variables affecting biomolecule production. Response surface methodology (RSM) was used to find the optimum concentration of these important variables, and thereby used to enhance the production of acid proteases (Siala et al. 2012), fibrinolytic enzymes (Vijayaraghavan and Vincent 2014) and $\beta$-galactosidase (Raol et al. 2015). In this study, optimization of medium components involved in fibrinolytic enzyme production by Bacillus cereus IND5 using fish waste and cow dung substrate was carried out using RSM. Based on our knowledge, no work is available regarding fibrinolytic enzyme production using the mixture of these feedstock (fish waste and cow dung) in solid state fermentation. Hence, this substrate was selected for the production of fibrinolytic enzyme.

\section{Materials and methods}

\section{Screening of organism producing fibrinolytic enzyme}

About $1 \mathrm{~g}$ fermented rice was mixed with $100 \mathrm{ml}$ distilled water. Sample was taken from it and screened for organisms showing proteolytic activity using skimmed milk agar plates. Ten bacterial cultures, which showed clear zone in the casein agar plates, were further screened for fibrinolytic enzyme producing ability. The protease positive isolates were cultured in a medium containing peptone $(3.0 \%)$, glucose (1.0\%), $\mathrm{CaCl}_{2}(0.50 \%)$, and $\mathrm{MgSO}_{4}(0.20 \%)$. The $\mathrm{pH}$ of culture medium was brought to 7.0, and incubated at $37{ }^{\circ} \mathrm{C}$ for $72 \mathrm{~h}$ at $150 \mathrm{rpm}$ (Gad et al. 2014). After $72 \mathrm{~h}$ of incubation, the bacterial biomass was separated by centrifugation ( $8000 \mathrm{rpm}, 10 \mathrm{~min}$, and $4{ }^{\circ} \mathrm{C}$ ) and the extract devoid of cells was used to screen fibrinolytic enzyme activity. Fibrin plate assay was used to assess the fibrinolytic activity of the extracts. The fibrinolytic protease activity appeared as a halo zone around the fibrin clot after incubation at $37{ }^{\circ} \mathrm{C}$ for a period of $5 \mathrm{~h}$.

\section{Identification of the bacterial isolate}

A bacterial isolate (IND5), which showed good activity based on the above screening procedures, was further identified using biochemical and morphological tests (Bednarski 2006). The 16S rRNA sequencing was carried out using the forward (5'AGAGTTTGATCMTGGCT $\mathrm{AG}^{\prime}$ ) and reverse primer ( $5^{\prime}$ ACGGGCGGTGTGTRC $3^{\prime}$ ) (Rejiniemon et al. 2015). Amplification of 16S rRNA gene was carried out using a gradient PCR machine (Peng et al. 2004). The available sequence was compared using NCBI BLAST and the organism was identified as Bacillus cereus IND5.

\section{Solid state fermentation (SSF)}

Cuttle fish was collected from Kanniyakumari coast and its by-product was prepared (Souissi et al. 2008). Briefly, gut, 
stomach and head were removed, rinsed with double distilled water, heated, minced and dried well at $80 \pm 2{ }^{\circ} \mathrm{C}$ for $48 \mathrm{~h}$. Cow dung substrate was processed as described previously (Vijayaraghavan et al. 2012). Equal amount of cuttle fish and cow dung waste were mixed and used as the substrate. $5 \mathrm{~g}$ of substrate $(2.5 \mathrm{~g}$ cuttle fish waste $+2.5 \mathrm{~g}$ cow dung) was taken in $100 \mathrm{ml}$ Erlenmeyer flasks and the $\mathrm{pH}$ of the solid substrate medium was adjusted to 8.0 by the addition of $0.1 \mathrm{M}$ tris- $\mathrm{HCl}$ buffer. The moisture content of SSF medium was adjusted to $70 \%(\mathrm{v} / \mathrm{w})$. During the preliminary experiments, the Erlenmeyer flasks were incubated at $37^{\circ} \mathrm{C}$ for $72 \mathrm{~h}$, and at $96 \mathrm{~h}$, the maximum production of fibrinolytic enzyme was registered. Hence, all fermentations were run for a period of $72 \mathrm{~h}$.

\section{Submerged fermentation}

In the present study, B. cereus IND5 was cultured in submerged fermentation to compare the yield with that of SSF. For this, $100 \mathrm{ml}$ nutrient broth medium (beef extract, $5 \mathrm{~g} / \mathrm{l}$; peptone, $5 \mathrm{~g} / \mathrm{l}$; yeast extract, $1.5 \mathrm{~g} / \mathrm{l}$; and sodium chloride) was prepared, sterilized and inoculated with $0.1 \mathrm{ml}$ of $18 \mathrm{~h}$ grown $B$. cereus IND5. The Erlenmeyer flask was incubated at $37{ }^{\circ} \mathrm{C}$ for $48 \mathrm{~h}$. The culture was centrifuged at $10,000 \mathrm{rpm}$ for $10 \mathrm{~min}$ and the cell free supernatant was used as the crude enzyme.

\section{Fibrinolytic enzyme assay}

The enzyme $(0.1 \mathrm{ml})$ was mixed with $2.5 \mathrm{ml}$ of tris- $\mathrm{HCl}$ buffer ( $\mathrm{pH} 7.8)$ containing calcium chloride $(0.01 \mathrm{M})$. Fibrinolytic activity was assayed on fibrin substrate. The absorbance was read at $275 \mathrm{~nm}$ (Anson 1938; Chang et al. 2000). Enzyme activity was calculated based on the calibration curve drawn for standard solution of L-Tyrosine. One unit of fibrinolytic enzyme activity (U) was defined as the amount of enzyme which liberates $1 \mu \mathrm{g}$ of tyrosine per min under the standard assay condition. The results of the determination of fibrinolytic activity were described in units of activity/gram of substrate (U/g).

\section{Selection of important medium components for fibrinolytic enzyme production by one variable at a time approach}

In the present study, the mixture of cuttle fish waste and cow dung was used as the substrate for the optimization of enzyme production. The effect of six different carbon sources namely, glucose, starch, trehalose, xylose, sucrose, and maltose on the production of fibrinolytic enzyme was studied. To evaluate the influence of nitrogen sources, beef extract, casein, gelatin, urea, and yeast extract were employed. The solid medium was supplemented with ammonium chloride, ammonium sulfate, calcium chloride, di-sodium hydrogen phosphate $\left(\mathrm{Na}_{2} \mathrm{HPO}_{4}\right)$, ferrous sulfate, sodium di-hydrogen phosphate $\left(\mathrm{NaH}_{2} \mathrm{PO}_{4}\right)$, and sodium nitrate, to evaluate the influence of ions on production of enzyme. These nutrients were supplemented with the substrate individually. The substrate was mixed carefully with tris $\mathrm{HCl}$ buffer $(\mathrm{pH} 8.0)$ to adjust the initial moisture to $70 \%$. Then, $500 \mu \mathrm{l}$ inoculum $(10 \%$, v/w) was introduced into the medium and incubated as described previously. Fifty milliliter of ice cold double distilled water was poured with the fermented medium and shaken at $150 \mathrm{rpm}$ for $30 \mathrm{~min}$. It was further centrifuged at a speed of $10,000 \mathrm{rpm}$ for $20 \mathrm{~min}$ in a centrifuge maintained at $4{ }^{\circ} \mathrm{C}$. The cell free extract was stored and utilized for fibrinolytic enzyme assay.

\section{Screening of vital medium components using two-level full factorial design}

A two-level full factorial statistical design, a preliminary medium optimization strategy to find the important medium components in fibrinolytic enzyme production, was employed in this study. For screening of vital medium components, five variables, $\mathrm{pH}$, moisture, sucrose, casein and $\mathrm{MgSO}_{4}$ were selected. In two-level full factorial design, each variable is represented at the low $(-)$ level and high $(+)$ level. The design model is based on the first order polynomial equation:

$Y=\alpha_{0}+\sum_{i} \alpha_{i} x_{i}+\sum_{i j} \alpha_{i j} x_{i} x_{j}+\sum_{i j k} \alpha_{i j k} x_{i} x_{j} x_{k}$,

where $\alpha_{0}, \alpha_{i}, \alpha_{i j}$ and $\alpha_{i j k}$ represent the intercept, $i$ th linear coefficient, $i j$ th interaction coefficient and the $i j k$ th interaction coefficient, respectively. SSF process was initiated in $100 \mathrm{ml}$ Erlenmeyer flasks and the same were maintained at $37{ }^{\circ} \mathrm{C}$ for $72 \mathrm{~h}$ using an incubator. Each experiment was carried out in duplicate and average value was presented. After statistical analysis using analysis of variance (ANOVA), the important factors were identified. DesignExpert 9.0 (StatEase Inc, Minneapolis, USA) was sought for the design of experiments and statistical analysis of data.

\section{Response surface methodology}

The significant medium ingredients $(\mathrm{pH}$, casein, and $\mathrm{MgSO}_{4}$ ) affecting fibrinolytic enzyme production, as observed by the two-level full factorial design, were tested for interactive effects using a central composite design (CCD) of response surface methodology. The selected variables were coded as $\mathrm{A}(\mathrm{pH}), \mathrm{B}$ (casein), and $\mathrm{C}$ $\left(\mathrm{MgSO}_{4}\right)$ and the following second order model equation was used to predict the response (Eq. 2).

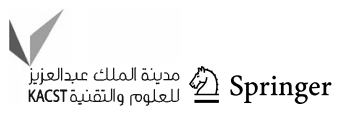


$Y=\beta_{0}+\sum_{i=1}^{3} \beta_{i} X_{i}+\sum_{i=1}^{3} \beta_{i i} X_{i}^{2}+\sum_{i j=1}^{3} \beta_{i j} X_{i j}$.

The experimental runs were performed in $100 \mathrm{ml}$ Erlenmeyer flasks as per the central composite design in randomized manner. The substrate was sterilized at $121{ }^{\circ} \mathrm{C}$ for $20 \mathrm{~min}$ and cooled. After which, 10\% inoculum (B. cereus IND5) were carefully inoculated under aseptic conditions. SSF was carried out in an incubator maintained at $37{ }^{\circ} \mathrm{C}$ for a period of $72 \mathrm{~h}$. After fermentation, enzyme in the SSF medium was extracted and enzyme assay was carried out. The ANOVA was used to evaluate the significant model terms. The optimum medium composition was obtained using RSM and these optimum conditions were validated. Design-Expert 9.0 (StatEase Inc, Minneapolis, USA) was the software program employed to design the experiment and to analyze the data.

\section{Purification of fibrinolytic enzyme from $B$. cereus IND5}

The fibrinolytic enzyme was produced through SSF using B. cereus IND5 using the optimized culture medium. The crude enzyme was purified by performing ammonium sulfate precipitation, diethyl aminoethyl cellulose (DEAE cellulose) and casein-agarose affinity chromatography. $50 \mathrm{ml}$ of crude extract was precipitated and $70 \%$ saturation was attained by the addition of ammonium sulfate salt. The precipitate was separated out by centrifugation $\left(10,000 \mathrm{rpm}, 4{ }^{\circ} \mathrm{C}\right)$ and was dissolved in $0.1 \mathrm{M}$ tris- $\mathrm{HCl}$ buffer ( $\mathrm{pH}$ 8.0). It was further dialyzed against water (two changes) and buffer (third change). The sample was further loaded on a DEAE-cellulose column which was pre equilibrated with $0.05 \mathrm{M}$ tris- $\mathrm{HCl}$ buffer ( $\mathrm{pH} 8.0$ ). The bounded proteins were eluted with $0.05 \mathrm{M}$ tris buffer containing 0-1.0 M NaCl. $\mathrm{NaCl}$ gradient was made using a gradient maker and all fractions were collected manually. The fractions $(2.0 \mathrm{ml})$ were analyzed for their protein concentration (Absorbance $280 \mathrm{~nm}$ ) and enzyme activity. The active fractions were loaded on casein-agarose affinity chromatography (Sigma, USA) which was pre equilibrated with $0.02 \mathrm{M}$ tris- $\mathrm{HCl}$ buffer. Elution of the proteins was done with a gradient of buffer with strength of $0-0.8 \mathrm{M}$ $\mathrm{NaCl}$. The fractions resulting from elution were assayed for fibrinolytic activity. In each step of enzyme purification, enzyme assay and also total protein estimation were carried out. Further, specific activity of enzyme, yield, and purification fold were also measured.

\section{SDS-PAGE analysis and zymography}

The highly active fraction from DEAE cellulose chromatography and affinity chromatography was subjected to analysis for homogeneity. The enzyme sample was added with SDS sample buffer and boiled for $1 \mathrm{~min}$ before loading on to the SDS-PAGE gel (12\%). The molecular markers used were soybean trypsin inhibitor of $20.1 \mathrm{kDa}$, carbonic anhydrase of $29 \mathrm{kDa}$, ovalbumin of $43 \mathrm{kDa}$, bovine serum albumin of $66 \mathrm{kDa}$ and phosphorylase $\mathrm{b}$ of $97.4 \mathrm{kDa}$. The protein bands were visualized by staining using coomassie brilliant blue (R-250). For zymography analysis, a fibrin substrate containing polyacrylamide gel $(12 \%)$ was prepared by adding $0.12 \%(\mathrm{w} / \mathrm{v})$ fibrinogen and thrombin (100 NIH U/ml). The affinity chromatography purified-fraction was loaded on this gel. At the end of electrophoresis, the gel was taken out and incubated with buffer A containing $2.5 \%(\mathrm{v} / \mathrm{v})$ Triton X-100 for $30 \mathrm{~min}$ at room temperature $\left(30 \pm 1{ }^{\circ} \mathrm{C}\right)$. The residual Triton $\mathrm{X}-100$ was removed by washing the gel with double distilled water for $30 \mathrm{~min}$. The gel was incubated with buffer A for $4 \mathrm{~h}$. Then the gel was subjected to coomassie brilliant blue (R-250) staining for $2 \mathrm{~h}$ and then destained (overnight). The fibrinolytic activity of the enzyme was visualized as nonstained region on blue background.

\section{Evaluation of characteristics of the purified enzyme}

The optimal $\mathrm{pH}$ needed for the maximized fibrinolytic activity of enzyme, was estimated using buffers $(0.1 \mathrm{M})$ of different $\mathrm{pH}$ namely, $\mathrm{pH} 3.0$ and 4.0 (citrate buffer), $\mathrm{pH} 5.0$ (succinate buffer), $\mathrm{pH} 6.0$ and 7.0 (sodium phosphate buffer), $\mathrm{pH} 8.0$ (tris buffer) and $\mathrm{pH} 9.0$ and 10.0 (glycine$\mathrm{NaOH}$ buffer). To evaluate the stability of enzyme activity with respect to $\mathrm{pH}$, the fibrinolytic enzyme was incubated with the aforementioned buffers, separately and incubated at $37{ }^{\circ} \mathrm{C}$ for $1 \mathrm{~h}$ before adding the substrate. The influence of temperature on the activity of enzyme was estimated by performing the reactions at different temperatures of 30 , $40,50,60$, and $70{ }^{\circ} \mathrm{C}$. The stability of the fibrinolytic enzyme with respect to temperature was estimated by incubating it in the absence of substrate at different temperatures, $30-70{ }^{\circ} \mathrm{C}$ for $1 \mathrm{~h}$. Fibrinolytic activity of the enzyme was assayed as described earlier. To elucidate the influence of divalent ions on enzyme activity, the enzyme was incubated for $30 \mathrm{~min}$ along with different divalent ions, namely $\mathrm{Ca}^{2+}, \mathrm{Cu}^{2+}, \mathrm{Co}^{2+}, \mathrm{Mg}^{2+}, \mathrm{Mn}^{2+}, \mathrm{Hg}^{2+}, \mathrm{Fe}^{2+}$, and $\mathrm{Zn}^{2+}$ at $0.01 \mathrm{M}$ concentrations (Lomate and Hivrale 2011). 


\section{Results and discussion}

\section{Screening and identification of the fibrinolytic enzyme producing bacterium}

Ten protease producing bacterial isolates were selected after casein hydrolysis. These protease positive isolates were further evaluated for production of fibrinolytic enzyme using fibrin plate. Among the ten bacterial cultures, the cell free extract of an isolate named IND5 produced the highest halo zone than other isolates (Fig. 1). The halo zone represents the clearance of fibrin which in turn indicates the fibrinolytic activity of the strains. The isolate IND5 also produced more fibrinolytic enzyme in submerged fermentation compared to the other isolates. The 16S rDNA sequence of the isolate IND5 was subjected to BLAST and the sequence showed a high similarity with Bacillus cereus. The strain was identified as $B$. cereus IND5 and accession number was assigned (KF250421).

\section{Production of fibrinolytic enzyme in submerged fermentation}

B. cereus IND5 was cultured in nutrient broth medium and enzyme production was found to be $73 \mathrm{U} / \mathrm{ml}$ after $48 \mathrm{~h}$ of incubation at $37{ }^{\circ} \mathrm{C}$. Submerged fermentation has been widely used for the production of enzymes. Recently, Bajaj et al. (2014) used submerged fermentation for the production of fibrinolytic enzyme from Bacillus sp.

\section{Cuttle fish waste and cow dung mixture for fibrinolytic enzyme production in SSF}

In SSF, enzyme production was found to be maximum after $72 \mathrm{~h}$ incubation at $37{ }^{\circ} \mathrm{C}(1205 \pm 48 \mathrm{U} / \mathrm{g})$. SSF technique has been widely used for the production of enzymes, antibiotics, secondary metabolites, flavoring compounds

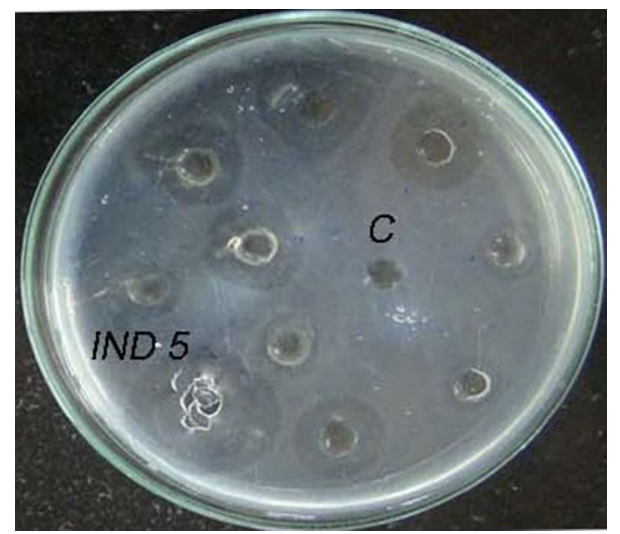

Fig. 1 Fibrinolytic enzyme activity of the bacterial isolates on fibrin plate (C-control) and also animal feeds. SSF process is defined as the one in which microbes get attached to solid materials and grow, without any free water. In SSF process, the solid substrate provides anchorage for the cells and supply nutrients. Hence, the native-like environment is created for the organism and maximum product production is expected. In recent years, many substrates were mixed and used as the fermentation medium to confirm its balanced nutritive value. The mixture of substrates, such as, protein and chitin (Wang et al. 2008b), powdered crab and shrimp shell (Oh et al. 2000), cuttlefish by-products powder and wastewater from fish processing industry (Souissi et al. 2008), cuttlefish and shrimp by-products (Ben Rebah et al. 2008) were used for the production of various enzymes. The by-products from fish processing support growth of microbes in an excellent manner. Due to its low cost and easily available nature, these substrates play a significant role in the production of enzyme (Rebah and Miled 2013). Mukherjee et al. (2008) used a mixture of potato peel with Imperata cylindrica grass as the substrate and produced fibrinolytic enzyme. Cow dung was reported as a novel substrate for use in SSF aimed at the production of cellulases (Vijayaraghavan et al. 2016a) and fibrinolytic enzymes (Vijayaraghavan et al. 2016b). Ghorbel et al. (2005) stated the importance of balanced nutrients for enzyme production by microbes. Considering the importance of balanced diet, the combination of cuttlefish by-product and cow dung was used as a substrate for the production of fibrinolytic enzyme. This result establishes the use of cuttle fish waste and cow dung mixture for fibrinolytic enzyme production. In enzyme bioprocess, no defined culture medium has been proposed to enhance the production of enzymes from various microbial sources. Every organism is unique in the requirement of its own environmental and nutritive factors for more enzyme production. Hence, optimization of enzyme production by an individual organism is a key to enhance enzyme production. These kinds of studies would provide low cost substrates for enzyme production in industries.

\section{Use of one variable at a time approach (OVAT) for screening medium components}

The traditional OVAT experiment helps to screen the variables without any complicated analysis. The mixture of cuttle fish waste and cow dung was used as the substrate for optimization of fibrinolytic enzyme production. In the present study, experiments were carried out with different carbon (glucose, starch, trehalose, xylose, sucrose, and maltose), nitrogen (beef extract, casein, gelatin, urea, and yeast extract) and ionic sources (ammonium chloride, magnesium sulfate, ammonium sulfate, calcium chloride, disodium hydrogen phosphate $\left(\mathrm{Na}_{2} \mathrm{HPO}_{4}\right)$, sodium di- 
hydrogen phosphate $\left(\mathrm{NaH}_{2} \mathrm{PO}_{4}\right)$, ferrous sulfate, and sodium nitrate) to evaluate the suitable nutrient source for the process of fibrinolytic enzyme production. All carbon sources, except glucose containing culture medium did not exhibit fibrinolytic activity than that of control and this indicated the inducible nature of $B$. cereus IND5 fibrinolytic enzyme. Among the carbon sources, sucrose stimulated more enzyme production (1218 $\pm 27 \mathrm{U} / \mathrm{g})$ (Fig. 2a). Hence, sucrose was used as the suitable carbon source. Vijayaraghavan and Vincent (2014) concluded that sucrose was the best carbon source for fibrinolytic enzyme production for Paenibacillus sp. IND8. Among the nitrogen sources, casein considerably enhanced fibrinolytic enzyme production $(1294 \pm 32 \mathrm{U} / \mathrm{g})$ (Fig. 2b). This result agreed with the observations made with Bacillus sp. strain AS-S20-I (Mukherjee and Rai 2011) and
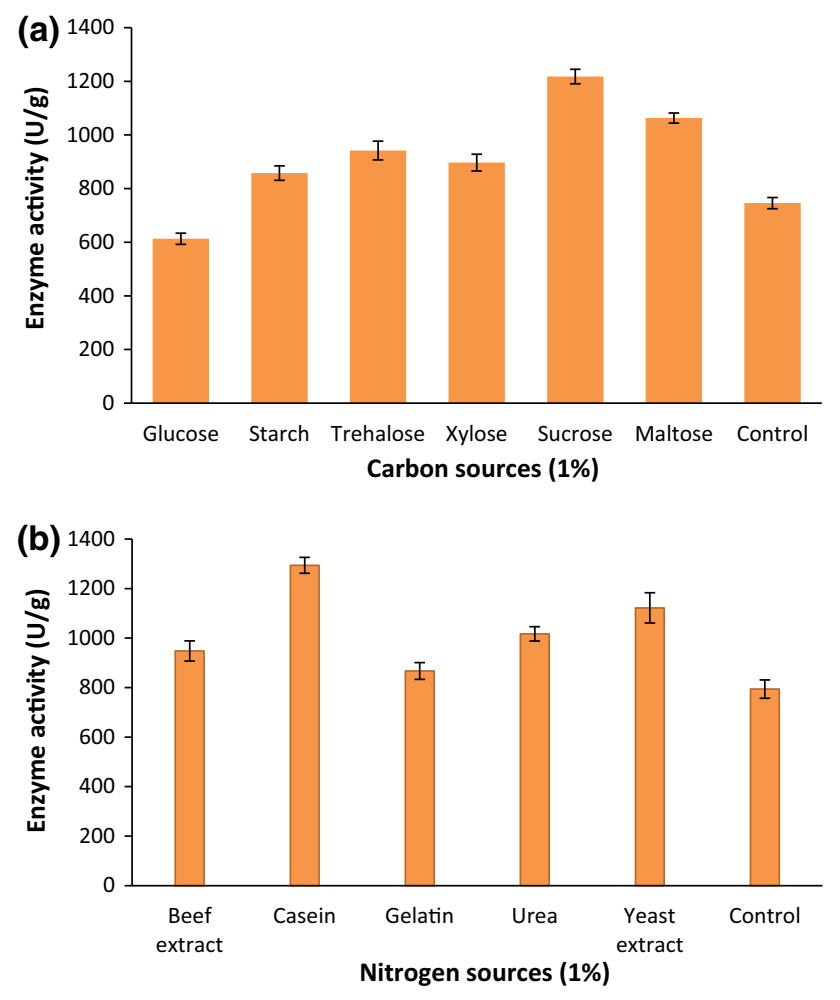

(c)

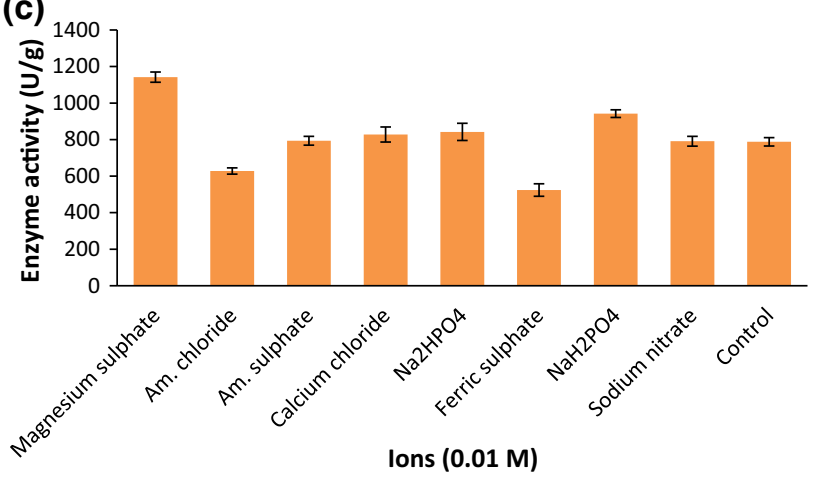

Fig. 2 Effect of carbon source (a) nitrogen source (b) and ion (c) on fibrinolytic enzyme production
Proteus penneri SP-20 (Jhample et al. 2015). $\mathrm{MgSO}_{4}(0.1 \%$, $\mathrm{w} / \mathrm{w}$ ) was found to be the best ionic source for production of fibrinolytic enzyme $(1142 \pm 28 \mathrm{U} / \mathrm{g})$. However, addition of ammonium chloride $(0.1 \%, \mathrm{w} / \mathrm{w})$ negatively influenced the enzyme production (Fig. 2c). Based on OVAT approach, sucrose, casein and $\mathrm{MgSO}_{4}$ were chosen for further experiments.

\section{Medium optimization using $2^{5}$ full factorial design}

In this study, cow dung and cuttle fish waste were (50:50) used for the production of enzyme. A two-level five factorial design is a best statistical tool for studying the production of fibrinolytic enzymes (Liu et al. 2005). This method analyzes the factors in two levels, i.e., high (+) and low (-), for the screening of important variables or factors (Table 1). From the results of preliminary screening carried out by OVAT approach, sucrose, casein and $\mathrm{MgSO}_{4}$ were selected as the suitable nutritional factors for evaluating fibrinolytic enzyme production. In this statistical design, along with these three variables, moisture and $\mathrm{pH}$ were also included as the critical factors for optimizing enzyme production in SSF. The variables and the results of the experiments were described in the Table 2. In this study, the production of fibrinolytic enzyme varied between 180 and $5044 \mathrm{U} / \mathrm{g}$. The production of enzyme was observed to be maximum in the medium containing $80 \%$ moisture content, $0.1 \%$ sucrose, $0.1 \%$ casein, $0.1 \% \mathrm{MgSO}_{4}$ and $\mathrm{pH}$ 7.0. ANOVA of the interactive effects were represented in the Table 3. The $F$ value of this model was 128.47 and it was statistically significant. There is only a little chance $(0.01 \%)$ that this much large "Model $F$-value" had occurred due to noise. Hence, the interactive tested variables were found to be statistically significant. The model terms A, B, D, $\mathrm{E}, \mathrm{AB}, \mathrm{AC}, \mathrm{AD}, \mathrm{AE}, \mathrm{BD}, \mathrm{BE}, \mathrm{CE}, \mathrm{DE}, \mathrm{ABC}, \mathrm{ABE}, \mathrm{ACD}$, ACE, ADE, BCD, BCE, BDE, ABCE, ACDE and BCDE were found to be significant. The predicted $R^{2}$ value $(0.9263)$ was found to be close to the adjusted $R^{2}$ value (0.9911). The $R^{2}$ value of this model was 0.9988 . The equation of the model can be written using coded levels of factors as:

Fibrinolytic enzyme activity

$$
\begin{aligned}
= & +2389.94-234.44 \mathrm{~A}-90.94 \mathrm{~B} \\
& -0.75 \mathrm{C}+120.50 \mathrm{D}-261.75 \mathrm{E}+553.06 \mathrm{AB}-79.87 \mathrm{AC} \\
& +179.13 \mathrm{AD}-385.75 \mathrm{AE}+35.87 \mathrm{BC}+182.75 \mathrm{BD} \\
& -84.00 \mathrm{BE}-35.44 \mathrm{CD}+86.31 \mathrm{CE}+108.06 \mathrm{DE} \\
& -577.88 \mathrm{ABC}-67.87 \mathrm{ABE}-261.81 \mathrm{ACD}-106.94 \mathrm{ACE} \\
& -58.44 \mathrm{ADE}-182.44 \mathrm{BCD}+331.81 \mathrm{BCE} \\
& +311.69 \mathrm{BDE}+21.37 \mathrm{CDE}+94.69 \mathrm{ABCE} \\
& -96.12 \mathrm{ACDE}-375.50 \mathrm{BCDE} .
\end{aligned}
$$

The negative coefficients for medium components $\mathrm{A}$ (pH), B (moisture), $\mathrm{C}$ (sucrose) and $\mathrm{E}\left(\mathrm{MgSO}_{4}\right)$ indicated 
Table 1 The independent variables chosen for $2^{5}$ factorial design and their coded levels

\begin{tabular}{|c|c|c|c|c|}
\hline \multirow[t]{2}{*}{ Symbol } & \multirow[t]{2}{*}{ Variables } & \multirow[t]{2}{*}{ Units } & \multicolumn{2}{|c|}{ Coded levels } \\
\hline & & & -1 & +1 \\
\hline A & $\mathrm{pH}$ & & 7 & 9 \\
\hline B & Moisture & $(\%)$ & 80 & 100 \\
\hline $\mathrm{C}$ & Sucrose & $(\%)$ & 0.1 & 1.0 \\
\hline $\mathrm{D}$ & Casein & $(\%)$ & 0.1 & 1.0 \\
\hline $\mathrm{E}$ & $\mathrm{MgSO}_{4}$ & $(\%)$ & 0.01 & 0.10 \\
\hline
\end{tabular}

Table 2 Randomized runs of $2^{5}$ factorial design and the measured response

\begin{tabular}{|c|c|c|c|c|c|c|}
\hline Run & A:pH & B:Moisture & C:Sucrose $(\%)$ & D:Casein $(\%)$ & $\mathrm{E}: \mathrm{MgSO}_{4}(\%)$ & Enzyme activity (U/g) \\
\hline 1 & 1 & 1 & 1 & -1 & 1 & 1693 \\
\hline 2 & -1 & -1 & -1 & 1 & 1 & 2730 \\
\hline 3 & 1 & -1 & 1 & 1 & 1 & 1258 \\
\hline 4 & -1 & 1 & 1 & 1 & -1 & 2019 \\
\hline 5 & 1 & -1 & 1 & 1 & -1 & 2997 \\
\hline 6 & -1 & -1 & 1 & -1 & 1 & 2320 \\
\hline 7 & 1 & -1 & -1 & 1 & 1 & 821 \\
\hline 8 & 1 & -1 & 1 & -1 & 1 & 1166 \\
\hline 9 & 1 & 1 & 1 & -1 & -1 & 2233 \\
\hline 10 & -1 & 1 & -1 & -1 & -1 & 2310 \\
\hline 11 & 1 & -1 & -1 & -1 & -1 & 530 \\
\hline 12 & 1 & 1 & -1 & -1 & -1 & 4251 \\
\hline 13 & 1 & -1 & -1 & -1 & 1 & 1546 \\
\hline 14 & -1 & 1 & -1 & -1 & 1 & 180 \\
\hline 15 & 1 & -1 & -1 & 1 & -1 & 2031 \\
\hline 16 & 1 & 1 & 1 & 1 & -1 & 2544 \\
\hline 17 & -1 & -1 & 1 & -1 & -1 & 2754 \\
\hline 18 & -1 & 1 & -1 & 1 & 1 & 1750 \\
\hline 19 & 1 & 1 & -1 & -1 & 1 & 230 \\
\hline 20 & -1 & -1 & -1 & -1 & -1 & 3587 \\
\hline 21 & -1 & 1 & 1 & 1 & 1 & 3605 \\
\hline 22 & 1 & -1 & 1 & -1 & -1 & 3198 \\
\hline 23 & -1 & 1 & -1 & 1 & -1 & 910 \\
\hline 24 & 1 & 1 & -1 & 1 & -1 & 4640 \\
\hline 25 & -1 & -1 & -1 & -1 & 1 & 5044 \\
\hline 26 & -1 & -1 & 1 & 1 & -1 & 2521 \\
\hline 27 & -1 & 1 & 1 & -1 & 1 & 2818 \\
\hline 28 & -1 & -1 & -1 & 1 & -1 & 3651 \\
\hline 29 & 1 & 1 & -1 & 1 & 1 & 3840 \\
\hline 30 & -1 & -1 & 1 & 1 & 1 & 3340 \\
\hline 31 & -1 & 1 & 1 & -1 & -1 & 2251 \\
\hline 32 & 1 & 1 & 1 & 1 & 1 & 1510 \\
\hline
\end{tabular}

that the enzyme production can be increased by decreasing their concentrations in the fermentation medium. The positive coefficient for the model term D (casein) indicated that enzyme production could be increased by increasing the amount of casein in the SSF medium. Based on the $F$ value from Table 3, the medium components casein, $\mathrm{MgSO}_{4}$ and $\mathrm{pH}$ were considered as the vital components for fibrinolytic enzyme production by $B$. cereus IND5 using cuttle fish waste and cow dung mixture. 
Table 3 ANOVA results for $2^{5}$ factorial design

\begin{tabular}{|c|c|c|c|c|c|c|}
\hline Source & Sum of squares & $d f$ & Mean square & $F$ value & $p$ value & \\
\hline Model & $4.876+007$ & 27 & $1.806 \mathrm{E}+006$ & 128.47 & 0.0001 & Significant \\
\hline A-pH & $1.759 \mathrm{E}+006$ & 1 & $1.759 \mathrm{E}+006$ & 125.13 & 0.0004 & \\
\hline B-Moisture & $2.646 \mathrm{E}+005$ & 1 & $2.646 \mathrm{E}+005$ & 18.83 & 0.0123 & \\
\hline C-Sucrose & 18.00 & 1 & 18.00 & $1.281 \mathrm{E}-003$ & 0.9732 & \\
\hline D-Casein & $4.646 \mathrm{E}+005$ & 1 & $4.646 \mathrm{E}+005$ & 33.06 & 0.0045 & \\
\hline E-MgSO 4 & $2.192 \mathrm{E}+006$ & 1 & $2.192 \mathrm{E}+006$ & 155.98 & 0.0002 & \\
\hline $\mathrm{AB}$ & $9.788 \mathrm{E}+006$ & 1 & $9.788 \mathrm{E}+006$ & 696.37 & $<0.0001$ & \\
\hline $\mathrm{AC}$ & $2.042 \mathrm{E}+005$ & 1 & $2.042 \mathrm{E}+005$ & 14.52 & 0.0189 & \\
\hline $\mathrm{AD}$ & $1.027 \mathrm{E}+006$ & 1 & $1.027 \mathrm{E}+006$ & 73.05 & 0.0010 & \\
\hline $\mathrm{AE}$ & $4.762 \mathrm{E}+006$ & 1 & $4.762 \mathrm{E}+006$ & 338.77 & $<0.0001$ & \\
\hline $\mathrm{BC}$ & 41184.50 & 1 & 41184.50 & 2.93 & 0.1621 & \\
\hline BD & $1.069 \mathrm{E}+006$ & 1 & $1.069 \mathrm{E}+006$ & 76.03 & 0.0010 & \\
\hline $\mathrm{BE}$ & $2.258 \mathrm{E}+005$ & 1 & $2.258 \mathrm{E}+005$ & 16.06 & 0.0160 & \\
\hline CD & 40186.13 & 1 & 40186.13 & 2.86 & 0.1661 & \\
\hline $\mathrm{CE}$ & $2.384 \mathrm{E}+005$ & 1 & $2.384 \mathrm{E}+005$ & 16.96 & 0.0146 & \\
\hline DE & $3.737 \mathrm{E}+005$ & 1 & $3.737 \mathrm{E}+005$ & 26.59 & 0.0067 & \\
\hline $\mathrm{ABC}$ & $1.069 \mathrm{E}+007$ & 1 & $1.069 \mathrm{E}+007$ & 760.25 & $<0.0001$ & \\
\hline $\mathrm{ABE}$ & $1.474 \mathrm{E}+005$ & 1 & $1.474 \mathrm{E}+005$ & 10.49 & 0.0317 & \\
\hline $\mathrm{ACD}$ & $2.193 \mathrm{E}+006$ & 1 & $2.193 \mathrm{E}+006$ & 156.05 & 0.0002 & \\
\hline $\mathrm{ACE}$ & $3.659 \mathrm{E}+005$ & 1 & $3.659 \mathrm{E}+005$ & 26.03 & 0.0070 & \\
\hline $\mathrm{ADE}$ & $1.093 \mathrm{E}+005$ & 1 & $1.093 \mathrm{E}+005$ & 7.77 & 0.0494 & \\
\hline $\mathrm{BCD}$ & $1.065 \mathrm{E}+006$ & 1 & $1.065 \mathrm{E}+006$ & 75.77 & 0.0010 & \\
\hline BCE & $3.523 \mathrm{E}+006$ & 1 & $3.523 \mathrm{E}+006$ & 250.65 & $<0.0001$ & \\
\hline BDE & $3.109 \mathrm{E}+006$ & 1 & $3.109 \mathrm{E}+006$ & 221.17 & 0.0001 & \\
\hline $\mathrm{CDE}$ & 14620.50 & 1 & 14620.50 & 1.04 & 0.3654 & \\
\hline $\mathrm{ABCE}$ & $2.869 \mathrm{E}+005$ & 1 & $2.869 \mathrm{E}+005$ & 20.41 & 0.0107 & \\
\hline ACDE & $2.957 \mathrm{E}+005$ & 1 & $2.957 \mathrm{E}+005$ & 21.04 & 0.0101 & \\
\hline BCDE & $4.512 \mathrm{E}+006$ & 1 & $4.512 \mathrm{E}+006$ & 321.00 & $<0.0001$ & \\
\hline Residual & 56223.75 & 4 & 14055.94 & & & \\
\hline Cor total & $4.881 \mathrm{E}+007$ & 31 & & & & \\
\hline
\end{tabular}

\section{Optimized enzyme production SSF process using RSM}

RSM is an ideal statistical tool for optimizing enzyme production. Recently, RSM was applied for optimized production of cellulases (Singh et al. 2014; Premalatha et al. 2015), fibrinolytic enzyme (Majumdar et al. 2015) and xylanase (Khusro et al. 2016). The optimum concentration of individual process parameters considering the interactive effect were elucidated using RSM. Hence, the vital parameters were taken at five levels and SSF was done according to CCD. The factors and their levels were described in Table 4. The enzyme activity was found to vary from 1488 to $5364 \mathrm{U} / \mathrm{g}$ (Table 5). ANOVA was used to evaluate the results and the model was statistically significant with $F$ value of 1276.39 (Table 6). The chance of interplay of noise in the appearance of this much large
$F$ value is as little as $0.01 \%$. The model terms A, B, C, $\mathrm{AC}, \mathrm{AB}, \mathrm{BC}, \mathrm{A}^{2}, \mathrm{~B}^{2}$ and $\mathrm{C}^{2}$ were significant. The "Lack of fit $F$ value" of 1.02 implies the insignificance of lack of fit as compared to the pure error. There was an estimated chance of $48.97 \%$ that a "Lack of Fit-value" of this magnitude could occur owing to noise. "The Pred R-squared" of 0.9960 was close to the "Adj R-Squared" of 0.9983 . The second order polynomial equation is given below.

$$
\begin{aligned}
\text { Enzyme activity }= & +3432.41+540.01 \mathrm{~A}-100.97 \mathrm{~B} \\
& -568.45 \mathrm{C}-729.25 \mathrm{AB}+658.00 \mathrm{AC} \\
& -552.25 \mathrm{BC}-155.19 \mathrm{~A}^{2}+32.55 \mathrm{~B}^{2}+30.07 \mathrm{C}^{2} .
\end{aligned}
$$

To deduce the optimum concentration of each variable for the enhancement of enzyme production 3D surface 
Table 4 The independent variables selected for CCD and their coded values

\begin{tabular}{lllllll}
\hline Variables & Symbol & \multicolumn{2}{l}{ Coded values } & & \\
\cline { 2 - 6 } & & $-\alpha$ & -1 & 0 & +1 & $+\alpha$ \\
\hline $\mathrm{pH}$ & $\mathrm{A}$ & 6.32 & 7 & 8 & 9 & 9.68 \\
Casein & $\mathrm{B}$ & -0.21 & 0.10 & 0.55 & 1.00 & 1.31 \\
$\mathrm{MgSO}_{4}$ & $\mathrm{C}$ & 0.01 & 0.03 & 0.05 & 0.07 \\
\hline
\end{tabular}

Table 5 Central composite design runs and results

\begin{tabular}{|c|c|c|c|c|}
\hline Run & A:pH & B:Casein & $\mathrm{C}: \mathrm{MgSO}_{4}$ & Enzyme activity (U/g) \\
\hline 1 & -1.000 & 1.000 & -1.000 & 5201 \\
\hline 2 & 0.000 & 0.000 & -1.682 & 4457 \\
\hline 3 & 0.000 & 0.000 & 0.000 & 3421 \\
\hline 4 & 1.000 & -1.000 & 1.000 & 5364 \\
\hline 5 & 0.000 & -1.682 & 0.000 & 3682 \\
\hline 6 & 0.000 & 1.682 & 0.000 & 3358 \\
\hline 7 & 0.000 & 0.000 & 0.000 & 3425 \\
\hline 8 & -1.682 & 0.000 & 0.000 & 2126 \\
\hline 9 & 0.000 & 0.000 & 0.000 & 3410 \\
\hline 10 & 0.000 & 0.000 & 0.000 & 3512 \\
\hline 11 & 1.000 & 1.000 & -1.000 & 3528 \\
\hline 12 & 0.000 & 0.000 & 0.000 & 3430 \\
\hline 13 & -1.000 & -1.000 & 1.000 & 1488 \\
\hline 14 & 0.000 & 0.000 & 0.000 & 3398 \\
\hline 15 & 0.000 & 0.000 & 1.682 & 2569 \\
\hline 16 & 1.000 & -1.000 & -1.000 & 4107 \\
\hline 17 & 1.682 & 0.000 & 0.000 & 3852 \\
\hline 18 & 1.000 & 1.000 & 1.000 & 2609 \\
\hline 19 & -1.000 & 1.000 & 1.000 & 1617 \\
\hline 20 & -1.000 & -1.000 & -1.000 & 2830 \\
\hline
\end{tabular}

Table 6 ANOVA for CCD design results

\begin{tabular}{llrlrr}
\hline Source & Sum of squares & $d f$ & Mean square & $F$ value & $p$ value \\
\hline Model & $1.910 \mathrm{E}+007$ & 9 & $2.122 \mathrm{E}+006$ & 1276.39 & $<0.0001$ \\
$\mathrm{~A}-\mathrm{pH}$ & $3.982 \mathrm{E}+006$ & 1 & $3.982 \mathrm{E}+006$ & 2395.44 & $<0.0001$ \\
$\mathrm{~B}-\mathrm{Casein}$ & $1.392 \mathrm{E}+005$ & 1 & $1.392 \mathrm{E}+005$ & 83.74 & $<0.0001$ \\
$\mathrm{C}-\mathrm{MgSO}{ }_{4}$ & $4.413 \mathrm{E}+006$ & 1 & $4.413 \mathrm{E}+006$ & 2654.43 & $<0.0001$ \\
$\mathrm{AB}$ & $4.254 \mathrm{E}+006$ & 1 & $4.254 \mathrm{E}+006$ & 2559.06 & $<0.0001$ \\
$\mathrm{AC}$ & $3.464 \mathrm{E}+006$ & 1 & $3.464 \mathrm{E}+006$ & 2083.43 & $<0.0001$ \\
$\mathrm{BC}$ & $2.440 \mathrm{E}+006$ & 1 & $2.440 \mathrm{E}+006$ & 1467.57 & $<0.0001$ \\
$\mathrm{~A}^{2}$ & $3.471 \mathrm{E}+005$ & 1 & $3.471 \mathrm{E}+005$ & 208.77 & $<0.0001$ \\
$\mathrm{~B}^{2}$ & 15266.04 & 1 & 15266.04 & 9.18 & 0.0127 \\
$\mathrm{C}^{2}$ & 13032.65 & 1 & 13032.65 & 7.84 & 0.0188 \\
Residual & 16625.01 & 10 & 1662.50 & & 0.4897 \\
Lack of fit & 8413.68 & 5 & 1682.74 & 1.02 & Not significant \\
Pure error & 8211.33 & 5 & 1642.27 & & \\
Cor total & $1.911 \mathrm{E}+007$ & 19 & & & \\
\hline
\end{tabular}



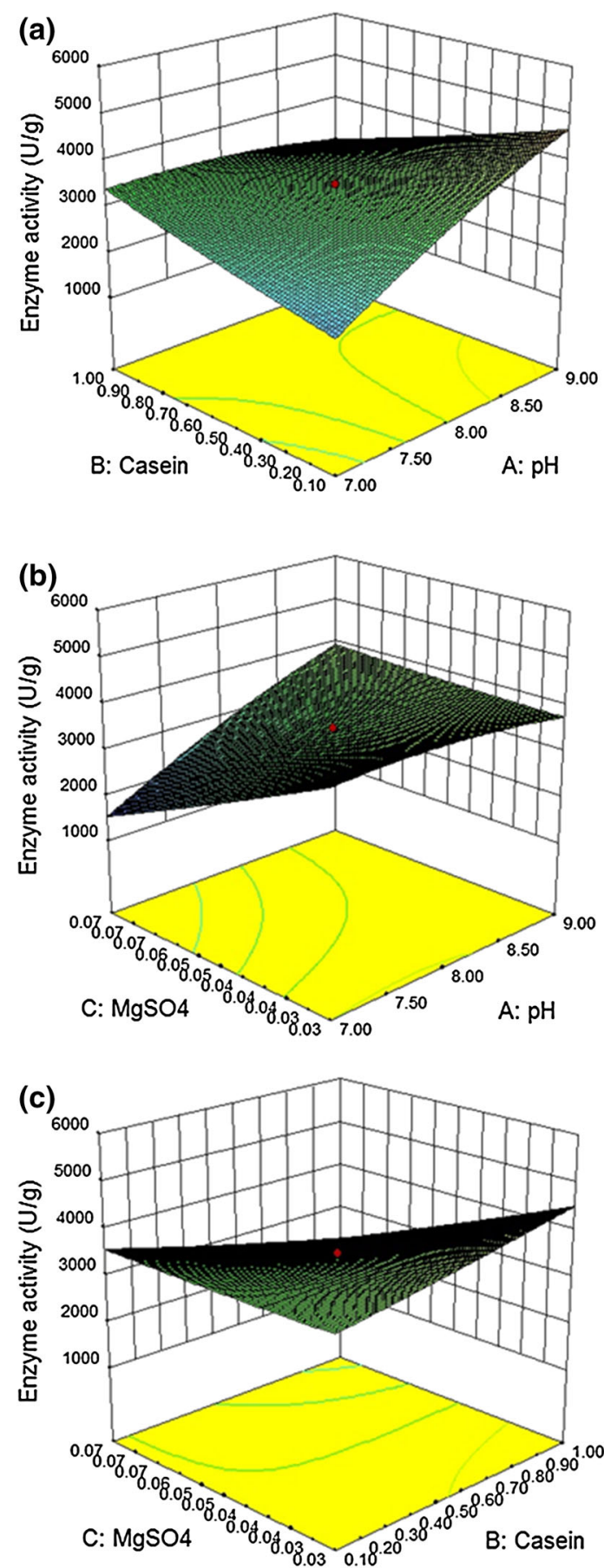

Fig. 3 Three dimensional response surface plots showing the effect of (a) $\mathrm{pH}$ and casein, (b) $\mathrm{pH}$ and $\mathrm{MgSO}_{4}$ and (c) casein and $\mathrm{MgSO}_{4}$

plots were constructed using RSM (Fig. 3). The optimized values of $\mathrm{pH}$, casein and $\mathrm{MgSO}_{4}$ were 7.8, 1.1 and $0.08 \%$, respectively. To check the predicted response, a validation experiment was conducted. Under the optimum levels of medium components, the fibrinolytic enzyme production was observed to be $5247 \pm 37 \mathrm{U} / \mathrm{g}$. The predicted response $5201 \mathrm{U} / \mathrm{g}$ was close to the observed results and this (a)

(b)

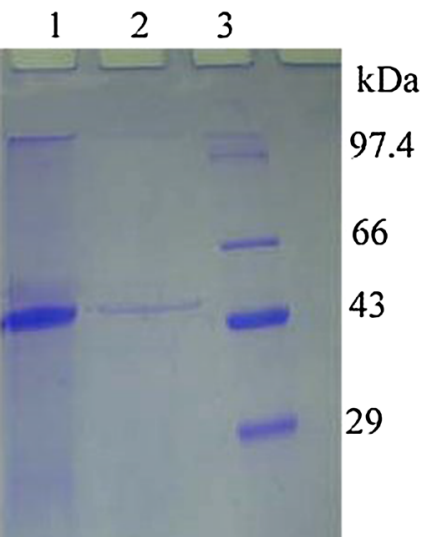

20.1

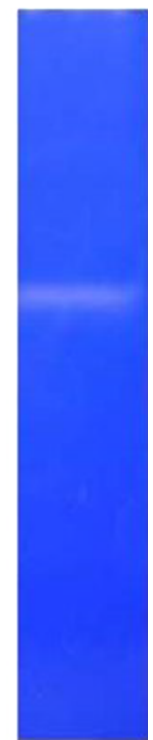

Fig. 4 a SDS-polyacrylamide gel electrophoresis (12\%) after coomassie staining. lane 1-DEAE-cellulose fraction; lane 2-affinity chromatography purified enzyme; lane 3-molecular markers. b Fibrin zymography showing the purified fibrinolytic enzyme from B. cereus IND5

validated the selected model. This finding shows the aptness of the selected model, indicating that the optimized levels of medium components favor the fibrinolytic enzyme production in SSF.

The culture medium cost is approximately $30-40 \%$ of total production cost of enzymes (Joo et al. 2003), hence the application of low cost substrate could reduce the overall enzyme cost. In the present observation, enzyme yield was found to be high in SSF than submerged fermentation. The processing cost of cow dung and cuttle fish waste was approximately $10 \mathrm{INR} / \mathrm{kg}$ material. The cost of one of the commercially available culture medium (Nutrient broth, HIMEDIA, Mumbai, India) was approximately $4 \mathrm{INR} / \mathrm{g}$ material. The approximate yield and production medium cost was $1400 \mathrm{U} / \mathrm{INR}$ in submerged fermentation, whereas 500,000 U/INR in SSF. The media cost was more than 100 times cheap in SSF than submerged fermentation. Thus, the use of cuttle fish waste and cow dung could reduce minimum $30 \%$ of overall enzyme cost.

\section{Downstream purification of the produced fibrinolytic enzyme}

In this study, fibrinolytic enzyme was purified by the combination of ammonium sulfate precipitation, DEAEcellulose column chromatography and affinity chromatography using casein-agarose matrix. The ammonium sulfate 

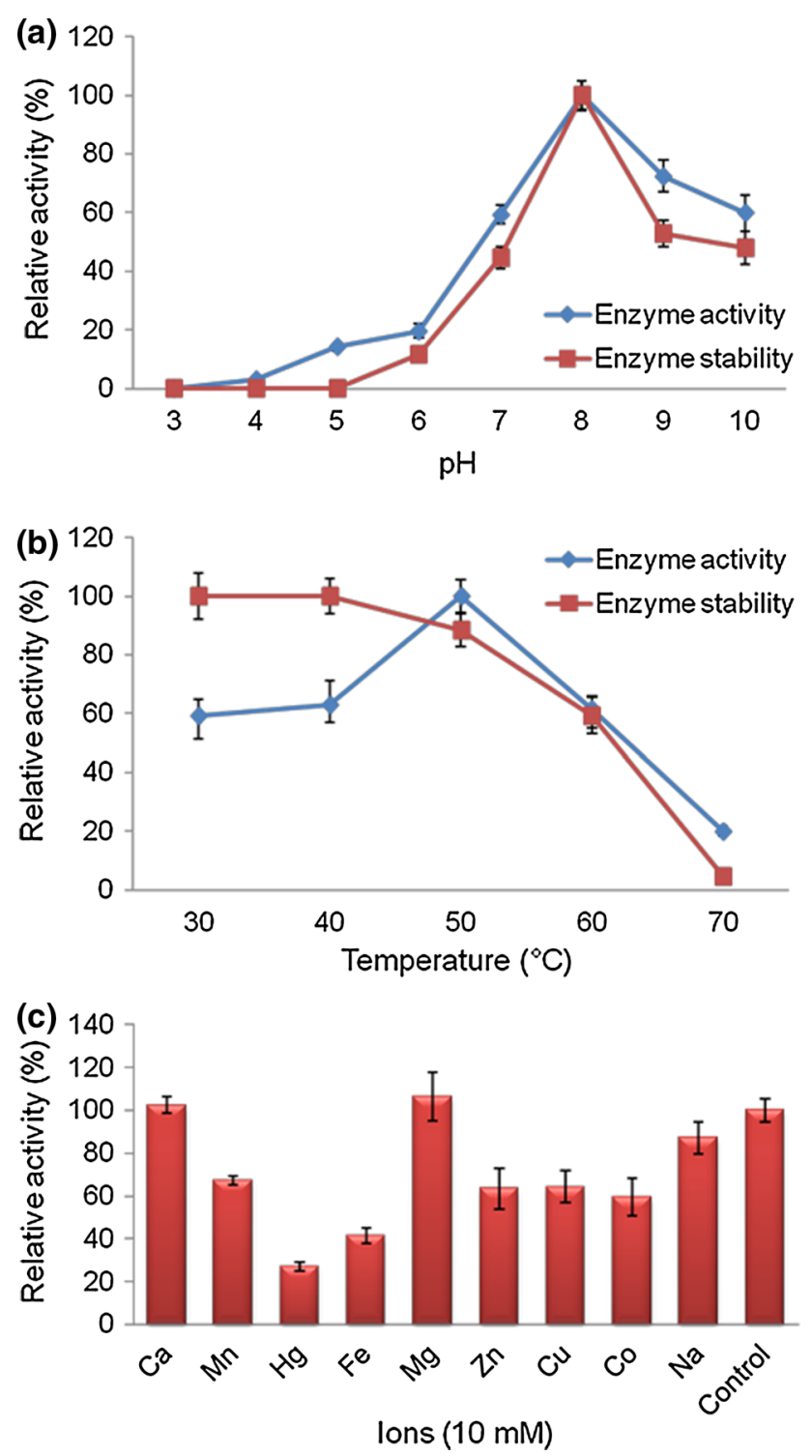

Fig. 5 Biochemical characterization of the purified fibrinolytic enzyme. a Effect of $\mathrm{pH}$ on enzyme activity and stability. Enzyme assay was carried out at $37{ }^{\circ} \mathrm{C}$. b Effect of temperature on enzyme activity and stability. Enzyme assay was carried out at $\mathrm{pH} 8.0$ with $0.1 \mathrm{M}$ Tris buffer. c Effect of various ions on enzyme activity. Enzyme assay was carried out at $\mathrm{pH} 8.0$ and at $50{ }^{\circ} \mathrm{C}$

precipitation showed 22,040 $\mathrm{U}$ of fibrinolytic enzyme with $43 \%$ yield, and 1.3-fold purification was achieved. The specific activity of fibrinolytic enzyme was increased to $143 \mathrm{U} / \mathrm{mg}$ protein after DEAE-cellulose chromatography purification. The affinity chromatography purified fractions showed $364.5 \mathrm{U} / \mathrm{mg}$ protein. The highly active fraction from DEAE cellulose and casein-agarose chromatography fractions was analyzed for its homogeneity. The DEAE chromatography fractions showed partial purification of enzyme. The affinity purified enzyme migrated as a single band in SDS-PAGE gel and the molecular weight was found to be $47 \mathrm{kDa}$ (Fig. 4). The molecular weight of bacterial fibrinolytic enzyme varies widely. In $B$. subtilis KCK-7, the molecular weight was registered as $44 \mathrm{kDa}$ (Paik et al. 2004); however, the molecular weight of fibrinolytic enzyme from $B$. subtilis LD-8547 was reported as $30 \mathrm{kDa}$ (Wang et al. 2008a).

\section{Characterization of the produced fibrinolytic enzyme}

The characterization of the purified enzyme was done by analyzing the effect of temperature, $\mathrm{pH}$, and ionic strength on its stability and activity. Figure 5a revealed the effect of $\mathrm{pH}$ on enzyme activity and stability. B. cereus IND5 fibrinolytic enzyme showed maximum activity at $\mathrm{pH} 8.0$ and was stable in the range of $\mathrm{pH}$ from 7.0 to 9.0 which throws light on the possible applications of this enzyme in a plethora of industrial sectors. This result was acceptable with respect to the previously published results. The fibrinolytic enzyme isolated from various Bacillus sp. showed optimum activity in the range, $\mathrm{pH}$ 8.0-9.0 (Agrebi et al. 2010; Mahajan et al. 2012; Bajaj et al. 2013). B. cereus IND5 fibrinolytic enzyme showed maximum activity at $50{ }^{\circ} \mathrm{C}$ (Fig. 5b). Bajaj et al. (2013) reported that several Bacillus sp. fibrinolytic enzymes have shown optimum activity at $35-40{ }^{\circ} \mathrm{C}$. However, $60{ }^{\circ} \mathrm{C}$ was optimum for the activity of fibrinolytic enzyme produced from B. subtilis A26 (Agrebi et al. 2009). B. cereus IND5 fibrinolytic enzyme activity was inhibited by the presence of tested metal ions except $\mathrm{Mg}^{2+}$ and $\mathrm{Ca}^{2+}$ (Fig. 5c). It was previously reported that the fibrinolytic enzyme of $B$. subtilis A26 was activated in the presence of $\mathrm{Ba}^{2+}, \mathrm{Cu}^{2+}, \mathrm{K}^{+}, \mathrm{Mg}^{2+}, \mathrm{Mn}^{2+}$ and $\mathrm{Na}^{+}$and enzyme activity was inhibited by the addition of $\mathrm{Zn}^{2+}$ and $\mathrm{Hg}^{2+}$ (Agrebi et al. 2009). In B. subtilis ICTF-1, fibrinolytic enzyme activity was inhibited by ions like $\mathrm{Zn}^{2+}$, $\mathrm{Hg}^{2+}$ and $\mathrm{Fe}^{3+}$ (Mahajan et al. 2012).

\section{Conclusion}

The present study revealed that $B$. cereus IND5 effectively utilized cuttle fish waste and cow dung for its growth and enzyme production. This substrate could have unprecedented potential for the production of fibrinolytic enzyme. The interactions of $\mathrm{pH}$, casein, and magnesium sulfate were evaluated by response surface methodology. Fibrinolytic enzyme production was significantly increased by altering the medium $\mathrm{pH}$ and at increased concentration of casein. The purified enzyme was highly active at $50{ }^{\circ} \mathrm{C}$ and was stable up to $\mathrm{pH}$ 8.0. Considering these properties, it could be useful for various biotechnological applications. 
Acknowledgements The Deanship of Scientific Research at King Saud University is gratefully acknowledged for providing fund to this Prolific Research Group (PRG-1437-28).

\section{Compliance with ethical standards}

Conflict of interest The authors declare that they have no conflict of interest.

Open Access This article is distributed under the terms of the Creative Commons Attribution 4.0 International License (http:// creativecommons.org/licenses/by/4.0/), which permits unrestricted use, distribution, and reproduction in any medium, provided you give appropriate credit to the original author(s) and the source, provide a link to the Creative Commons license, and indicate if changes were made.

\section{References}

Adegunloye DV, Adetuyi FC, Akinyosoye FA, Doyeni MO (2007) Microbial analysis of compost using cowdung as booster. Pak J Nutr 6:506-510

Agrebi R, Haddar A, Hajji M, Frikha F, Manni L, Jellouli K, Nasri M (2009) Fibrinolytic enzymes from a newly isolated marine bacterium Bacillus subtilis A26: characterization and statistical media optimization. Can J Microbiol 55:1049-1061

Agrebi R, Hmider N, Hajji M, Ktari N, Haddar A, Zouari NH, Nasri M (2010) Fibrinolytic serine protease isolated from Bacillus amyloliquefaciens An6 grown on Mirabilis Jalapa tuber powders. Appl Biochem Biotechnol 162:75-88

Ahn MY, Hahn BS, Ryu KS, Kim JW, Kim I, Kim YS (2003) Purification and characterization of a serine protease with fibrinolytic activity from the dung beetles, Catharsius molossus. Thromb Res 112:339-347

Anson ML (1938) The estimation of pepsin, trypsin, papain, and cathepsin with hemoglobin. J Gen Physiol 22:79-89

Awarenet (2004) Handbook for the prevention and minimization of waste and valorization of by-products in European agro-food industries. Agro-food waste minimization and reduction network (AWARENET). Grow Programme, European Commission, pp 1-7

Bajaj BK, Sharma N, Singh S (2013) Enhanced production of fibrinolytic protease from Bacillus cereus NS-2 using cotton seed cake as nitrogen source. Biocatal Agric Biotechnol 2:204-209

Bajaj BK, Singh S, Khullar M, Singh K, Bhardwaj S (2014) Optimization of fibrinolytic protease production from Bacillus subtilis I-2 using agro-residues. Braz Arch Biol Technol 57:653-662

Bednarski A (2006) Identifying unknown bacteria using biochemical and molecular methods. Washington University, St Louis

Ben Rebah F, Frikha F, Kammoun W, Belbahri L, Gargouri Y, Miled N (2008) Culture of Staphylococcus xylosus in fish processing by-product-based media for lipase production. Lett Appl Microbiol 47:549-554

Blann AD, Landray MJ, Lip GY (2002) An overview of antithrombotic therapy. BMJ 325:762-765

Bode C, Runge MS, Smalling RW (1996) The future of thrombolysis in the treatment of acute myocardial infarction. Eur Heart $\mathbf{J}$ 17:55-60

Bozzano A, Sardà F (2002) Fishery discard consumption rate and scavenging activity in the northwestern Mediterranean Sea. ICES J Mar Sci 59:15-28

Bressollier P, Letourneau F, Urdaci M, Verneuil B (1999) Purification and characterization of a keratinolytic serine proteinase from
Streptomyces albidoflavus. Appl Environ Microbiol 65:2570-2576

Chang CT, Fan MH, Kuo FC, Sung HY (2000) Potent fibrinolytic enzyme from a mutant of Bacillus subtilis IMR-NK1. J Agric Food Chem 48:3210-3216

Dilipkumar M, Rajasimman M, Rajamohan N (2011) Optimization of inulinase production from garlic by Streptomyces sp. in solid state fermentation using statistical designs. Biotechnol Res Int. doi:10.4061/2011/708043

Dilipkumar M, Rajasimman M, Rajamohan N (2013) Enhanced inulinase production by Streptomyces sp. in solid state fermentation through statistical designs. 3 Biotech 3:509-515

Fujita M, Nomura K, Hong K, Ito Y, Asada A, Nishimuro S (1993) Purification and characterization of a strong fibrinolytic enzyme (nattokinase) in the vegetable cheese natto, a popular soybean fermented food in Japan. Biochem Biophys Res Commun 197:1340-1347

Fujita M, Ito Y, Hong K, Nishimuro S (1995) Characterization of nattokinase-degraded products from human fibrinogen or crosslinked fibrin. Fibrinolysis 9:157-164

Fulhage CD (2000) Reduce environmental problems with proper land application of animal manure. University of Missouri Extension, Columbia

Gad RG, Nirmala S, Sivvaswamy SN (2014) Fibrinolytic enzyme from Bacillus amyloliquefaciens: Optimisation and scale up studies. Int J Pharm Pharm Sci 6:370-378

Ghaly AE, Ramakrishnan VV, Brooks MS, Budge SM, Dave D (2013) Fish processing wastes as a potential source of proteins, amino acids and oils: a critical review. J Microb Biochem Technol 5:107-129

Ghorbel S, Soussi N, Ellouz YT, Duffosse L, Guerard F, Nazri M (2005) Preparation and testing of Sardinella protein hydrolysate as nitrogen source for extracellular lipase production by Rhizopus oryzae. World J Microbiol Biotechnol 21:33-38

Haddar A, Fakhfakh-Zouari N, Hmidet N, Frikha F, Nasri M, Kamoun AS (2010) Low-cost fermentation medium for alkaline protease production by Bacillus mojavensis A21 using hulled grain of wheat and Sardinella peptone. J Biosci Bioeng 110:288-294

He J, Chen S, Gu J (2007) Identification and characterization of Harobin, a novel fibrino(geno)lytic serine protease from a sea snake (Lapemis hardwickii). FEBS 581:2965-2973

Holden RW (1990) Plasminogen activators: pharmacology and therapy. Radiology 174:993-1001

Itoi Y, Horinaka M, Tsujimoto Y, Matsui H, Watanabe K (2006) Characteristic features in the structure and collagen-binding ability of a thermophilic collagenolytic protease from the thermophile Geobacillus collagenovorans MO-1. J Bacteriol 188:6572-6579

Jhample SB, Bhagwat PK, Dandge PB (2015) Statistical media optimization for enhanced production of fibrinolytic enzyme from newly isolated Proteus penneri SP-20. Biocatal Agric Biotechnol 4:370-379

Joo HS, Kumar CG, Park GC, Paik SR, Chang CS (2003) Oxidant and SDS-stable alkaline protease from Bacillus clausii I-52: production and some properties. J Appl Microbiol 95:267-272

Khusro A, Kaliyan BK, Al-Dhabi NA, Arasu MV, Agastian P (2016) Statistical optimization of thermo-alkali stable xylanase production from Bacillus tequilensis strain ARMATI. Electron $\mathrm{J}$ Biotechnol. doi:10.1016/j.ejbt.2016.04.002

Kim W, Choi K, Kim Y, Park H, Choi J, Lee Y, Oh H, Kwon I, Lee S (1996) Purification and characterization of a fibrinolytic enzyme produced from Bacillus sp. strain CK 11-4 screened from Chungkook-Jang. Appl Environ Microbiol 62:2482-2488

Liu J, Xing J, Chang T, Ma Z, Liu H (2005) Optimization of nutritional conditions for nattokinase production by Bacillus natto NLSSE using statistical experimental methods. Process Biochem 40:2757-2762 
Lomate PR, Hivrale VK (2011) Induction of leucine aminopeptidase (LAP) like activity with wounding and methyl jasmonate in pigeonpea (Cajanas cajan) suggests the role of these enzymes in plant defense in leguminosae. Plant Physiol Biochem 49:609-616

Mahajan PM, Nayak S, Lele SS (2012) Fibrinolytic enzyme from newly isolated marine bacterium Bacillus subtilis ICTF-1: Media optimization, purification and characterization. J Biosci Bioeng 113:307-314

Mahanta N, Gupta A, Khare SK (2008) Production of protease and lipase by solvent tolerant Pseudomonas aeruginosa PseA in solid-state fermentation using Jatropha curcas seed cake as substrate. Bioresour Technol 99:1729-1735

Majumdar S, Goswami S, Keppen C, Rai SK, Mukherjee AK (2015) Statistical optimization for improved production of fibrin (Ogen) olytic enzyme by Bacillus cereus strain FF01 and assessment of in vitro thrombolytic potential of protease enzyme. Biocatal Agric Biotechnol 4:191-198

Mukherjee AK, Rai SK (2011) A statistical approach for the enhanced production of alkaline protease showing fibrinolytic activity from a newly isolated Gram-negative Bacillus sp. strain AS-S20I. N Biotechnol 28:182-189

Mukherjee AK, Adhikari H, Rai SK (2008) Production of alkaline protease by a thermophilic Bacillus subtilis under solid-state fermentation (SSF) condition using Imperata cylindrical grass and potato peel as low cost medium: characterization and application of enzyme in detergent formulation. Biochem Eng $\mathbf{J}$ 39:353-361

Oh YS, Shih IL, Tzeng YM, Wang SL (2000) Protease produced by Pseudomonas aeruginosa K-187 and its application in the deproteinization of shrimp and crab shell wastes. Enzym Microb Technol 27:3-10

Paik HD, Lee SK, Heo S, Kim SY, Lee H, Kwon TJ (2004) Purification and characterization of the fibrinolytic enzyme produced by Bacillus subtilis KCK-7 from Chungkookjang. J Microbiol Biotechnol 14:829-835

Pandey A, Soccol CR, Mitchell D (2000) New developments in solid state fermentation: I-bioprocesses and products. Process Biochem 35:1153-1169

Peng Y, Yang XJ, Xiao L, Zhang YZ (2004) Cloning and expression of a fibrinolytic enzyme (subtilisin DFE) gene from Bacillus amyloliquefaciens DC-4 in Bacillus subtilis. Res Microbiol 155:167-173

Prakasham RS, Rao CS, Sarma PN (2006) Green gram husk-an inexpensive substrate for alkaline protease production by Bacillus sp. in solid-state fermentation. Bioresour Technol 97:1449-1454

Premalatha N, Gopal NO, Jose PA, Anandham R, Kwon SW (2015) Optimization of cellulase production by Enhydrobacter sp. ACCA2 and its application in biomass saccharification. Front Microbiol. doi:10.3389/fmicb.2015.01046

Raol GG, Raol BV, Prajapati VS, Bhavsar NH (2015) Utilization of agro-industrial waste for $\beta$-galactosidase production under solid state fermentation using halotolerant Aspergillus tubingensis GR1 isolate. 3 Biotech 5:411-421

Rebah FB, Miled N (2013) Fish processing wastes for microbial enzyme production: a review. 3 Biotech 3:255-265

Rejiniemon TS, Hussain RR, Rajamani B (2015) In-vitro functional properties of Lactobacillus plantarum isolated from fermented ragi malt. South Ind J Biol Sci 1:15-23

Salihu A, Sallau AB, Adamu A, Kudu FA, Tajo MM, Bala TF, Yashim WD (2014) Utilization of groundnut husk as a solid substrate for cellulase production by Aspergillus niger using response surface methodology. Waste Biomass Valoriz 5:585-593

Siala R, Frikha F, Mhamdi S, Nasri M, Sellami Kamoun A (2012) Optimization of acid protease production by Aspergillus niger I1 on shrimp peptone using statistical experimental design. Sci World J. doi:10.1100/2012/564932

Singh K, Richa K, Bose H, Karthik L, Kumar G, Rao KV (2014) Statistical media optimization and cellulase production from marine Bacillus VITRKHB. 3. Biotech 4:591-598

Souissi N, Ellouz-Triki Y, Bougatef A, Blibech M, Nasri M (2008) Preparation and use of media for protease-producing bacterial strains based on by-products from Cuttlefish (Sepia officinalis) and wastewaters from marine-products processing factories. Microbiol Res 163:473-480

Sugimoto S, Fujii T, Morimiya T, Johdo O, Nakamura T (2007) The fibrinolytic activity of a novel protease derived from a tempeh producing fungus, Fusarium sp. BLB. Biosci Biotechnol Biochem 71:2184-2189

Sumi H, Hamada H, Tsushima H, Mihara H, Muraki H (1987) A novel fibrinolytic enzyme (nattokinase) in the vegetable cheese Natto; a typical and popular soybean food in the Japanese diet. Experientia 43:1110-1111

Sumi H, Hamada H, Nakanishi K, Hiratani H (1990) Enhancement of the fibrinolytic activity in plasma by oral administration of nattokinases. Acta Haematol 84:139-143

Sumi H, Nakajima N, Mihara H (1992) Fibrinolysis relating substances in marine creatures. Comp Biochem Physiol B 102:163-167

Triki-Ellouz Y, Ghorbel B, Souissi N, Kammoun S, Nasri M (2003) Biosynthesis of protease by Pseudomonas aeruginosa MN7 grown on fish substrate. World J Microbiol Biotechnol 19:41-45

Turpie AG (2002) Pentasaccharides. Semin Hematol 39:158-171

Vázquez JA, González MP, Murado MA (2006) Preliminary tests on nisin and pediocin production using waste protein sources: factorial and kinetic studies. Bioresour Technol 97:605-613

Vijayaraghavan P, Vincent SG (2012) Cow dung as a novel, inexpensive substrate for the production of a halo-tolerant alkaline protease by Halomonas sp. PV1 for eco-friendly applications. Biochem Eng J 69:57-60

Vijayaraghavan P, Vincent SG (2014) Statistical optimization of fibrinolytic enzyme production by Pseudoalteromonas sp. IND11 using cow dung substrate by response surface methodology. Springerplus. doi: 10.1186/2193-1801-3-60

Vijayaraghavan P, Vijayan A, Arun A, Jenisha JK, Vincent SG (2012) Cow dung: a potential biomass substrate for the production of detergent-stable dehairing protease by alkaliphilic Bacillus subtilis strain VV. Springerplus. doi:10.1186/2193-1801-1-76

Vijayaraghavan P, Arun A, Al-Dhabi NA, Vincent SG, Arasu MV, Choi KC (2016a) Novel Bacillus subtilis IND19 cell factory for the simultaneous production of carboxy methyl cellulase and protease using cow dung substrate in solid-substrate fermentation. Biotechnol Biofuels. doi:10.1186/s13068-016-0481-6

Vijayaraghavan P, Arun A, Vincent SG, Arasu MV, Al-Dhabi NA (2016b) Cow dung is a novel feedstock for fibrinolytic enzyme production from newly isolated Bacillus sp. IND7 and its application in in vitro clot lysis. Front Microbiol. doi: 10.3389/ fmicb.2016.00361

Wang CT, Ji BP, Li B, Nout R, Li PL, Ji H, Chen LF (2006) Purification and characterization of a fibrinolytic enzyme of Bacillus subtilis DC33, isolated from Chinese traditional Douchi. J Ind Microbiol Biotechnol 33:750-758

Wang SH, Zhang C, Yang YL, Diao M, Bai MF (2008a) Screening of a high fibrinolytic enzyme producing strain and characterization of the fibrinolytic enzyme produced from Bacillus subtilis LD8547. World J Microbiol Biotechnol 24:475-482

Wang SL, Hsu WT, Yen YH, Wang CL (2008b) Purification and characterization of three novel keratinolytic metalloproteases produced by Chryseobacterium indologenes TKU014 in a shrimp shell powder medium. Bioresour Technol 99:5679-5686

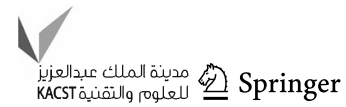

